\title{
Stipe Elongation in Agaricus bisporus
}

\author{
By G. D. CRAIG AND K. GULL \\ Biological Laboratory, University of Kent, Canterbury, Kent CT2 $7 \mathrm{NJ}$
}

AND D. A. WOOD

Glasshouse Crops Research Institute, Rustington, Littlehampton, Sussex BNI6 ${ }_{3} P U$

(Received 27 April 1977)

\begin{abstract}
Elongation of the stipe was investigated in Agaricus bisporus. The cell lengths in premarked regions of the stipe from base to top were compared. They were also compared with total stipe expansion and with the expansion occurring within the premarked regions. Cell elongation accounted for the elongation of the lower and mid-regions of the stipe but could not account for the elongation of the upper stipe region. Using autoradiography it was shown that there was a non-polar addition of new wall materials in the elongating cells of the stipe and, particularly in the upper stipe, cell division could be seen to occur by the formation of new septa. A model for cell growth in the elongating stipe of $A$. bisporus is described.
\end{abstract}

\section{INTRODUCTION}

The fruit bodies of basidiomycetes are the most complex differentiated structures formed by micro-organisms. The fruit body produces and disperses large numbers of basidiospores and the macroscopic appearance of the fruit body is a reflexion of the mechanism used to disperse the spores. The fruit body of Agaricus bisporus is composed of three main regions, the cap, gills and stipe. The cap protects the extensive gill surface which ultimately produces the basidiospores, and the stipe serves to raise these regions into a position suitable for spore dispersal.

The fruit body is first seen as a small mycelial aggregate which develops to the primordium stage. Differentiation into cap, gill and stipe regions occurs in the early primordium which continues to grow slowly to the button stage (20 to $30 \mathrm{~mm}$ in height). Further development is characterized by a gross expansion of the cap and gills and a rapid elongation of the stipe.

The biochemical basis of stipe elongation is very poorly understood and most studies have concentrated on aspects of wall synthesis. Gooday (1972), working with Coprinus cinereus, found that elongation of the stipe is accompanied by a considerable increase in chitin content and that there is a very high level of chitin synthase, particularly at the stage of maximum elongation. There is a low level of chitin synthase activity in the stipe at the end of elongation (Gooday, 1973). The antibiotic polyoxin D, which specifically inhibits chitin synthase in fungi (Corbett, 1974), prevents elongation of stipes of $C$. cinereus (Gooday, de Rousset-Hall \& Hunsley, 1976). Polyoxin D also inhibits the growth of mycelia and sporophores of $A$. bisporus (Wood \& Hammond, 1977), and sporophores treated with polyoxin D showed low levels of chitin. These studies indicate that synthesis of chitin, and presumably of other wall components, is an essential part of stipe elongation.

There is general agreement that in various basidiomycetes the upper portion of the stipe expands to a much greater extent than the base. Eilers (1974) has shown that the upper 
two-thirds of the stipe of Coprinus radiatus is responsible for 80 to $90 \%$ of the total stipe expansion. Similar results have been obtained by Cox \& Niederpruem (1975) in a study of stipe elongation in $C$. cinereus. Cox \& Niederpruem (1975) point out, however, that maximum expansion is localized in the upper mid-region rather than at the extreme top of the stipe. Bonner, Kane \& Levey (1956) have shown that elongation of the much more robust stipe of Agaricus is achieved by expansion of the upper portions, with maximum elongation occurring at the extreme top of the stipe.

These studies on elongation of the whole stipe are not accompanied by studies which provide information on the cellular mechanisms involved in the elongation. Eilers (1974), working with fruit bodies of $C$. radiatus, found that stipe elongation appeared to involve cell elongation and cell division. He stated: 'During the stage of rapid elongation, cells in the upper two-thirds of the stipe increase 6-8 fold in length', and 'the number of cells in a row in the growing portion of the stipe doubled'. His method of determining whether or not cell division was occurring involved examining the tissue microscopically and measuring the number of cells in a longitudinal row in the growing zone at different stages of development.

Bonner et al. (1956), studying Agaricus, claimed that the vertical orientation of the hyphae in the upper stipe region was complete when the fruit body was $10 \mathrm{~mm}$ in length, and that from the $18 \mathrm{~mm}$ stage onward there was probably no increase in cell number in the stipe and that cell elongation could account for the total increase in stipe length. They measured the length of 24 cells in the growth zone and in the region just above the base of an $18 \mathrm{~mm}$ and a $55 \mathrm{~mm}$ fruit body. They found that for the $18 \mathrm{~mm}$ fruit body, the average cell lengths were $23 \mu \mathrm{m}$ in the growth zone and $4 \mathrm{I} \mu \mathrm{m}$ at the base; and for the $55 \mathrm{~mm}$ fruit body, the average cell lengths were $8 \mathrm{I} \mu \mathrm{m}$ in the growth zone and $43 \mu \mathrm{m}$ at the base. They concluded: 'If the extent of the growth zone is taken into account then there is a three-fold increase for both the total overall increase in height and the increase in the length of the cells'. Hagimoto (1964) also concluded that the degree of cell elongation in the growing zone of the stipe of $A$. bisporus is similar to the growth of the whole fruit body. These reports deal only with a few cell length measurements at restricted points in the developmental sequence and also the work with Agaricus has tended to equate cell length increases in restricted areas of the stipe with the overall (averaged) increase in stipe length. This leads to an oversimplification of the mechanisms involved in elongation. We have re-investigated the cellular basis for stipe elongation in Agaricus by comparing the cell lengths in small, premarked regions of the stipe and compared these to the total stipe expansion and the expansion occurring within each marked region. We present a simple model to describe the developmental sequence of the expanding stipe. Cell length measurements and predictions from the model are compared with results from autoradiographic analysis of cell-wall growth.

\section{METHODS}

Fruit bodies of Agaricus bisporus (Lange) Imbach (Somycel 22 commerial strain) were grown in blocks of compost, from commercial growing beds, placed in plastic trays and covered with polythene to maintain a high humidity. The trays were incubated at $18{ }^{\circ} \mathrm{C}$ with daily watering to ensure a high moisture level for fruiting.

Marking the stipe. A portion of the cap of small fruit bodies was removed to expose the top of the stipe and Indian ink, applied with a drawn-out Pasteur pipette, was used to mark divisions on the stipes. The length of each division was measured. A V-shaped longitudinal strip of outer tissue was removed from the whole length of the stipe using a scalpel (Fig. 1). This strip was cut transversely into its component sections and the sections were individually teased out in $5 \%(\mathrm{w} / \mathrm{v}) \mathrm{KOH}$ in small screw-capped bottles. A glass bead was added to each bottle and they were shaken overnight at room temperature on a wrist-action shaker. This method separated the hyphae, allowing easy measurement of the hyphal compartment lengths (cell lengths) using phase contrast microscopy on a Zeiss Universal microscope. The lengths of 100 cells from each section were measured and the mean cell length was calculated.

The fruit body was then allowed to expand until it had approximately doubled in size (Fig. 2). At this 


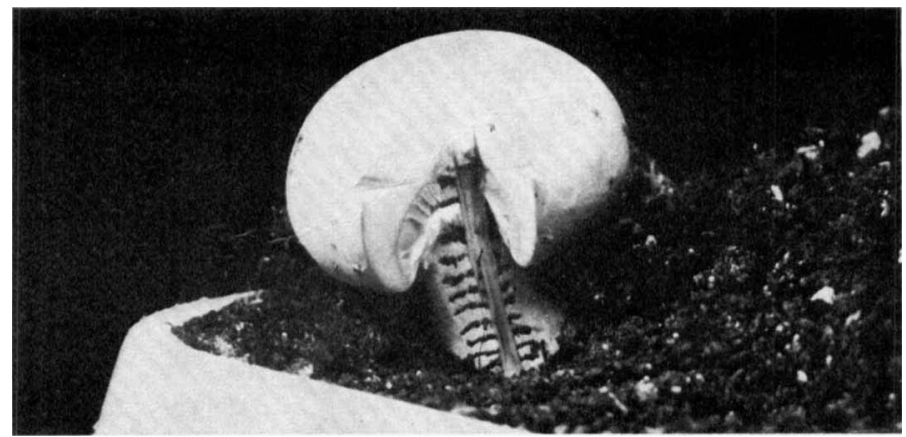

Fig. 1. Unexpanded fruit body A with the stipe marked into divisions using Indian ink. A portion of the cap has been removed to expose the top of the stipe and a longitudinal strip of stipe tissue has been removed.

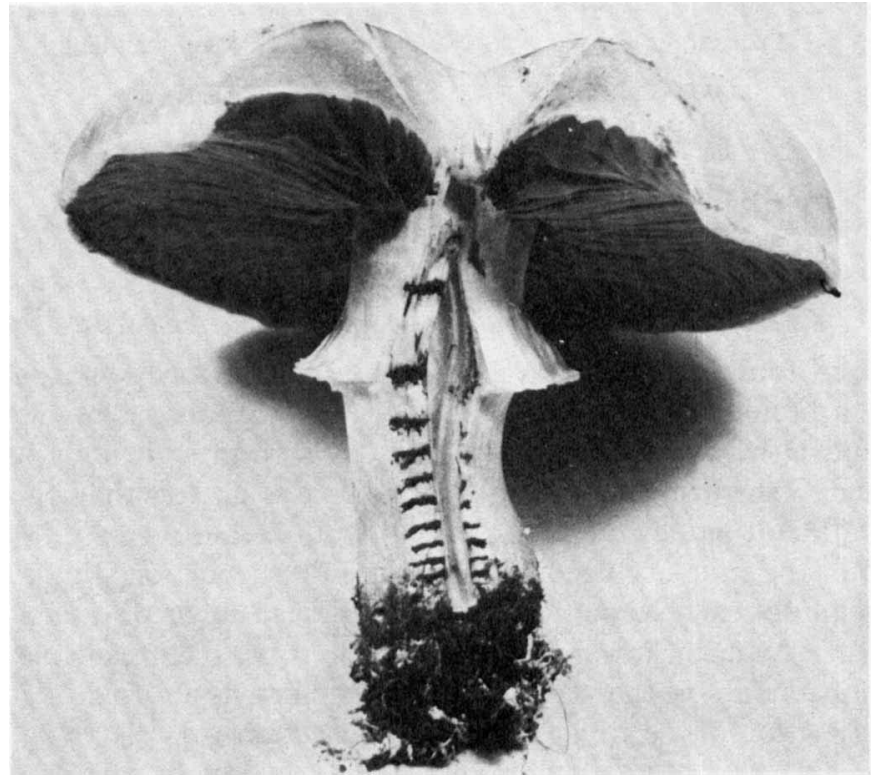

Fig. 2. Expanded fruit body A showing the extent of elongation of the divisions of the stipe.

time the length of each marked division and the mean cell length within each division were measured as before. The overall dimensions of each fruit body were also measured before and after expansion.

Throughout this study we use the term 'cell length' to indicate hyphal compartment length, that is the distance between two adjacent septa in a hypha.

Autoradiography. A total of $80 \mu \mathrm{l}$-acetyl-D-[1- $\left.{ }^{3} \mathrm{H}\right]$ glucosamine (specific activity $5 \mathrm{Ci} \mathrm{mM}^{-1}$; The Radiochemical Centre, Amersham) was injected, using a Hamilton syringe, in small aliquots into several areas of the stipe of small fruit bodies. After $30 \mathrm{~min}$ the stipe was marked into four equal sections, and a sample was taken from each section for autoradiography. The hyphae were separated by shaking overnight in $\mathrm{KOH}$ as before, then washed several times in distilled water and stained in $5 \%(\mathrm{w} / \mathrm{v})$ Congo red in $50 \%(\mathrm{v} / \mathrm{v})$ alcohol for $15 \mathrm{~min}$ at room temperature. The hyphae were washed several times in distilled water and kept in distilled water.

Stripping film autoradiography (applying Kodak AR-10 as recommended by the manufacturers) was used, and each sample was processed at least in triplicate. The film was exposed to the sample for 3 days at $4{ }^{\circ} \mathrm{C}$. The slides were developed in Kodak D-19 for $5 \mathrm{~min}$, rinsed, and fixed in Kodak Unifix fixer. They were mounted in Depex mounting medium and viewed in a Zeiss Universal microscope. Photography was carried out using Ilford Micro Neg Pan film type B rated at A.S.A. 3. 
Table I. Dimensions of fruit bodies $A, B, C$ and $D$, before and after expansion

\begin{tabular}{|c|c|}
\hline Fruit body & \\
\hline $\mathbf{A}$ & $\begin{array}{l}\text { Before expansion } \\
\text { After expansion }\end{array}$ \\
\hline B & $\begin{array}{l}\text { Before expansion } \\
\text { After expansion }\end{array}$ \\
\hline C & $\begin{array}{l}\text { Before expansion } \\
\text { After expansion }\end{array}$ \\
\hline D & $\begin{array}{l}\text { Before expansion } \\
\text { After expansion }\end{array}$ \\
\hline
\end{tabular}

Fruit body height

(mm)

$33 \cdot 0$

$65 \cdot 0$

$31 \cdot 0$

$79 \cdot 0$

$40 \cdot 0$

$95 \cdot 0$

$31 \cdot 0$

$75 \cdot 0$
Cap diameter
$(\mathrm{mm})$

$35 \cdot 0$

$70 \cdot 0$

$34 \cdot 0$

$116 \cdot 0$

$41 \cdot 0$

$118 \cdot 0$

$31 \cdot 0$
$76 \cdot 0$
Stipe length

(mm)

$24 \cdot 0$

$50 \cdot 5$

$21 \cdot 0$

$68 \cdot 0$

$30 \cdot 0$

$75 \cdot 0$

$21 \cdot 0$

$55 \cdot 0$

Table 2. Overall increases in stipe length and in mean cell length of the stipe in fruit bodies $A, B, C$ and $D$

\begin{tabular}{ccc} 
Fruit body & \multicolumn{2}{c}{ Overall expansion factor } \\
\cline { 2 - 3 } A & Stipe length & Mean cell length \\
B & $2 \cdot 1$ & $1 \cdot 4$ \\
C & $3 \cdot 2$ & $1 \cdot 4$ \\
D & $2 \cdot 5$ & $1 \cdot 5$ \\
& $2 \cdot 6$ & $1 \cdot 3$ \\
& & \\
Expansion of the fruit body of Agaricus bisporus
\end{tabular}

The expansion of four fruit bodies was followed from an early unexpanded stage to an expanded stage, a period of 72 to $96 \mathrm{~h}$ (Table $\mathrm{I}$ ). The expansion of the cap diameter in fruit bodies $A$ and $D$ was almost equal to the expansion in fruit body height, whereas in fruit bodies $B$ and $C$ the expansion in cap diameter was greater than the increase in fruit body height. In all fruit bodies there was a two- to threefold increase in the length of the stipe. Expansion of the stipe occurred mainly in the upper portion (Fig. 2). The percentage increase in the height of each section of the four stipes is shown on Fig. 4. There appeared to be a gradient of expansion towards the top of the stipe, the greatest expansion being in the uppermost portion, above the veil. There was as much as a 9-fold increase in the height of the uppermost section of the stipe (fruit body D, section 10 ).

\section{Comparison of cell length with the stage of development of the fruit body}

The mean length of 100 cells in each section of the stipes of fruit bodies A and D, before and after expansion, is shown in Fig. 3. There was a gradient of cell lengths in the stipe before expansion, with the longest ( 70 to $100 \mu \mathrm{m}$ ) at the base and the shortest (approximately $40 \mu \mathrm{m}$ ) at the apex (Fig. $3 a$ ). After expansion (Fig. $3 b$ ), the cell lengths in the upper sections of the stipe showed a marked increase, whereas the cell lengths in the lower sections of the base showed no increase. The mean cell lengths of stipes from very small fruit bodies (primordia), 7, IO and $14 \mathrm{~mm}$ in height, were $46 \cdot \mathrm{I}, 42 \cdot 2$ and $44 \cdot 2 \mu \mathrm{m}$, respectively.

\section{Comparison of overall growth of the stipe and growth in specific regions}

The overall increases in the lengths of the stipes of fruit bodies A, B, C and D were calculated from the lengths of the stipe before and after expansion. The overall increases in cell length were calculated from the mean cell lengths before and after expansion. The results (Table 2) show that the increase in cell length was considerably less than the increase in stipe length.

The percentage increase in the height of each section and the percentage increase in the mean cell length of each section of the four stipes are shown in Fig. 4. There was a gradient 


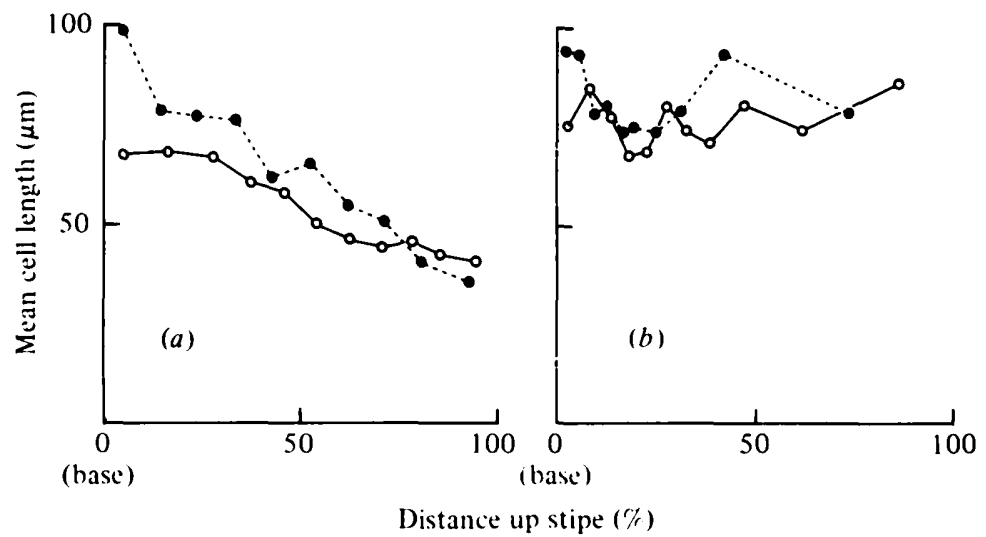

Fig. 3. Variation in the mean cell lengths in stipes of fruit bodies $A(O)$ and $D(0)$ with the percentage distance up the stipe, from base to top: (a) before expansion; (b) after expansion.
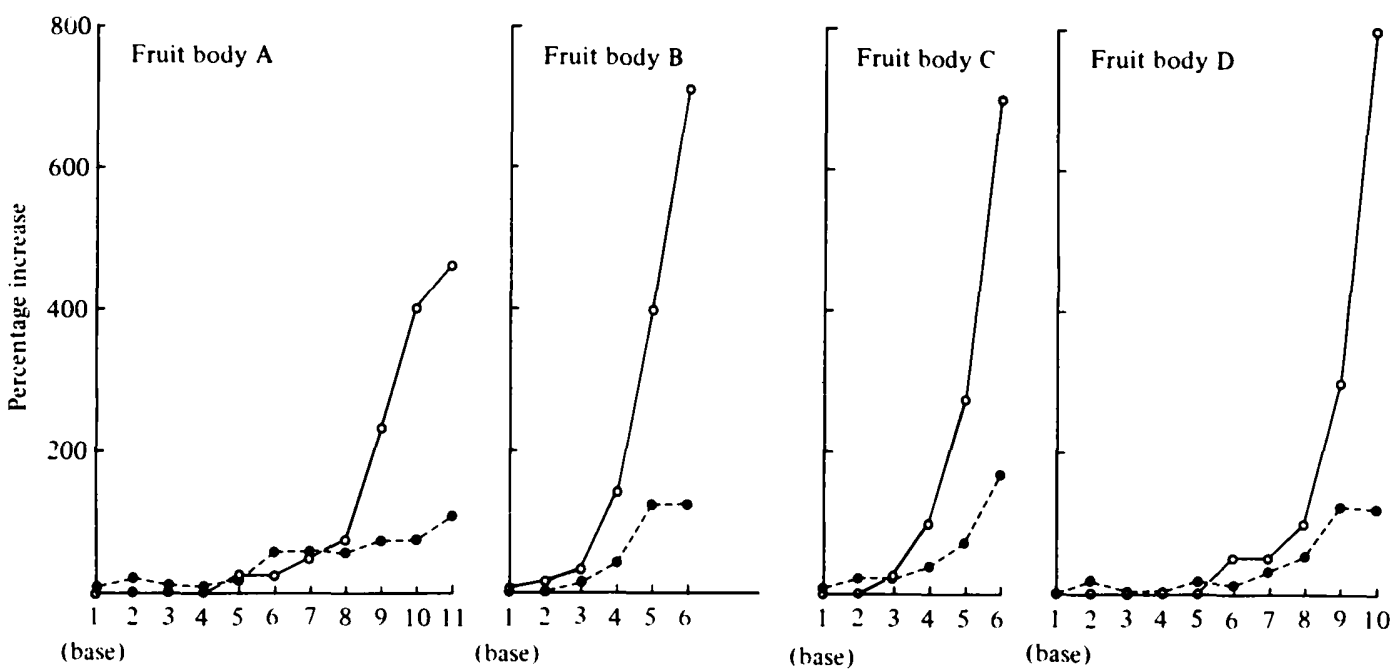

Section of stipe

Fig. 4. Percentage increases in the height of each section $(O)$ and in the mean cell length (O) in each section of the stipes of fruit bodies A, B, C and D after expansion.

of expansion in both section height and mean cell length up the stipe, the greatest expansion, in both cases, being at the apex. Elongation of the stipe sections of lower and mid-stipe was paralleled by an almost equivalent increase in cell length within each section, but in the upper sections of the stipe there was a marked difference in expansion. The nearer the section was to the top, the greater was the difference between the expansion of the section and the elongation of the cells. For example, in the top section of the stipe (section 10) of fruit body $D$ there were a 9 -fold increase in the height of the section, but only a $2 \cdot 2$-fold increase in the mean cell length.

\section{Incorporation of $\mathrm{N}$-acetyl-D-[ $\left[\mathrm{I}^{3} \mathrm{H}\right]$ glucosamine into stipe tissue}

The dimensions of four fruit bodies ( $\mathrm{E}$ to $\mathrm{H}$ ) examined are given in Table 3. $\mathrm{N}$-Acetyl-D$\left[{ }^{3}{ }^{3} \mathrm{H}\right]$ glucosamine was incorporated into the walls of the hyphae and often into the septa as well (Fig. 5). The number of silver grains visible on the walls was variable, some hyphae remaining unlabelled, some having a few grains and some hyphae having heavily-labelled walls. We calculated the percentages of cells and septa that were labelled for each of the four 
Table 3. Dimensions of fruit bodies $E, F, G$ and $H$

$\begin{array}{cccc}\text { Fruit body } & \begin{array}{c}\text { Fruit body height } \\ (\mathrm{mm})\end{array} & \begin{array}{c}\text { Cap diameter } \\ (\mathrm{mm})\end{array} & \begin{array}{c}\text { Stipe length } \\ (\mathrm{mm})\end{array} \\ \text { E } & 31 & 31 & 21 \\ \text { F } & 4 \text { I } & 46 & 28 \\ \text { G } & 56 & 55 & 38 \\ \text { H } & 64 & 69 & 52\end{array}$

Table 4. Quantitative autoradiography results, showing the percentages of labelled cells and septa in each of the four sections of the stipes of fruit bodies $E, F, G$ and $H$

$\begin{array}{clcc}\text { Fruit body } & \text { Stipe section } & \begin{array}{c}\text { Labelled cells } \\ (\%)\end{array} & \begin{array}{c}\text { Labelled septa } \\ (\%)\end{array} \\ \text { E } & \text { I (base) } & 35 \cdot 0 & 0 \cdot 6 \\ & 2 & 72 \cdot 6 & 12 \cdot 5 \\ & 3 & 15 \cdot 9 & 0 \\ \text { F } & 4 \text { (top) } & 33 \cdot 6 & 5 \cdot 5 \\ & \text { I (base) } & 22 \cdot 2 & 0 \cdot 9 \\ & 2 & 19 \cdot 9 & 1 \cdot 0 \\ \text { G } & 3 \text { (top) } & 6 \cdot 0 & 1 \cdot 0 \\ & 4 \text { I (base) } & 34 \cdot 3 & 16 \cdot 1 \\ & 2 & 11 \cdot 6 & 0 \\ \text { H } & 3 \text { (top) } & 20 \cdot 6 & 0 \cdot 8 \\ & 4 \text { I (base) } & 33 \cdot 6 & 3 \cdot 8 \\ & 2 & 41 \cdot 5 & 5 \cdot 2 \\ & 3 & 60 \cdot 3 & 6 \cdot 8 \\ & 4 \text { (top) } & 51 \cdot 3 & 1 \cdot 0 \\ & & 46 \cdot 8 & 1 \cdot 6 \\ \end{array}$

equal divisions of the four stipes (Table 4). A difficulty arises in assessing the significance of these values, as the amount of label incorporated may not be a reliable guide to the degree of cell expansion. Also, we cannot be sure that all the cells of the stipe which were examined were in contact with the label. However, in all fruit bodies, there was considerable incorporation into the walls in the top section of the stipe, and there were also labelled septa indicating that new septa were being formed.

\section{DISCUSSION}

There appears to be a gradient of expansion in the stipe of $A$. bisporus, with little or no expansion occurring at the base and the greatest expansion occurring in the uppermost region, above the veil. This is in agreement with the early work of Bonner et al. (I956) and is similar to the results obtained by Eilers (1974), working with $C$. radiatus.

Our results also indicate that there is a gradient of cell lengths in the stipe of the unexpanded fruit body, the longest cells $(70$ to $100 \mu \mathrm{m})$ being at the base and the shortest (about $40 \mu \mathrm{m}$ ) at the top. As the stipe expands, the cell lengths in the upper regions of the stipe increase to between 70 and $100 \mu \mathrm{m}$. Thus, after expansion, the mean cell length in all regions is between 70 and $100 \mu \mathrm{m}$. The mean cell length in the stipes of primordia was approximately $40 \mu \mathrm{m}$, which is similar to the lengths in the upper regions of the stipe before expansion. Therefore, we think that the following sequence of events occurs in the stipe during development. Initially the primordium has a stipe consisting of cells of about $40 \mu \mathrm{m}$ in length. The slow elongation of the stipe to about $20 \mathrm{~mm}$ is mainly achieved by expansion of the basal regions. This basal expansion is caused by cell elongation and results in the $20 \mathrm{~mm}$ stipe having longer cells.at its base than at the top. This initial expansion of the 

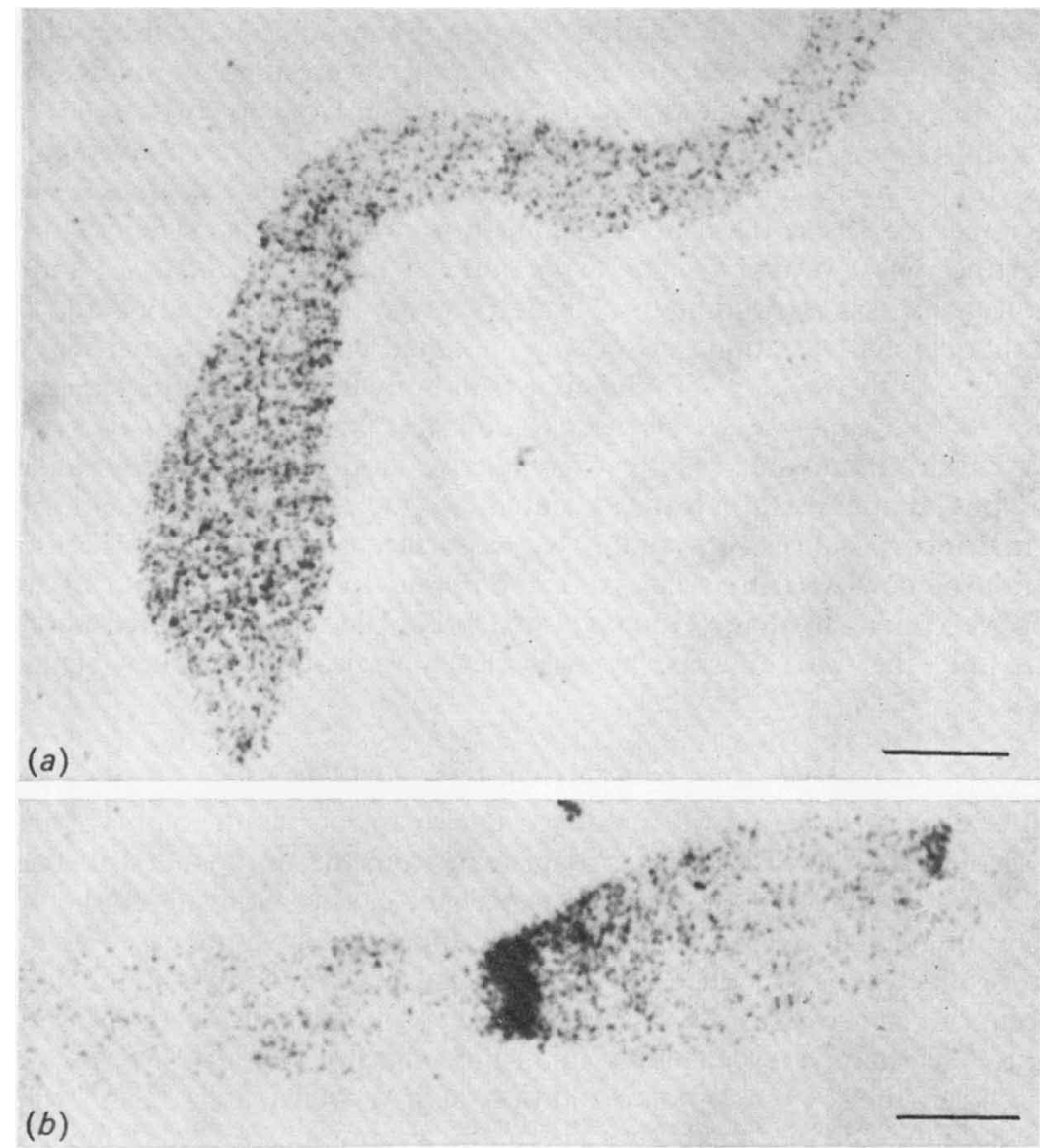

(b)
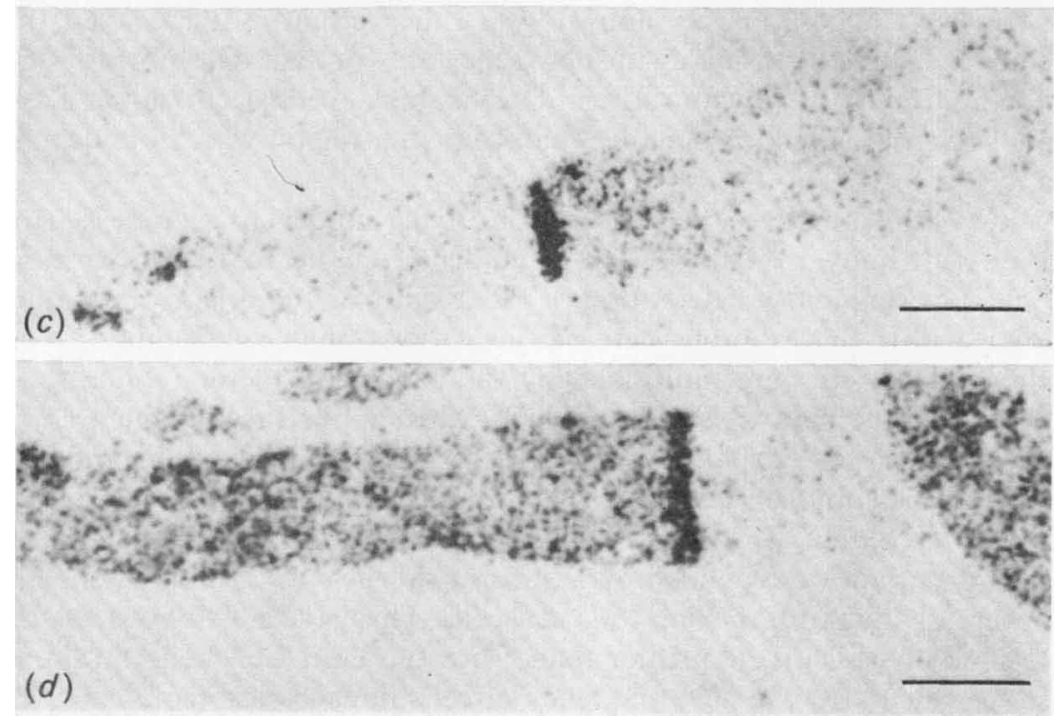

Fig. 5. Autoradiographs of elongating cells of the stipe of Agaricus bisporus, showing that (a) the label is located over the surface of the cells and $(b, c$ and $d)$ many septa are heavily labelled. Bar markers represent $10 \mu \mathrm{m}$. 
stipe may have a significant role in pushing the fruit body above ground level. The more rapid and extensive elongation of the stipe after the $20 \mathrm{~mm}$ stage is the result of cell elongation and, in the top sections, cell division. This process presumably involves the growth hormone, produced in the gills, described by Hagimoto \& Konishi (1959, 1960).

Previous reports on Agaricus have attempted to correlate the overall (average) expansion of the stipe with the overall (average) increase in cell length within the stipe. We have shown that, in the upper regions of the stipe, the elongation of the cells is far less than the elongation of the stipe. These results disagree with those of Bonner et al. (1956) and Hagimoto (1964). We feel that it is misleading to consider average increases in stipe and cell lengths because of the regional variations. Also, we eliminated any variation that may be present between fruit bodies by working with the same fruit body before and after expansion.

Elongation of the stipes of $C$. cinereus (Gooday, 1972; Gooday et al., 1976) and $A$. bisporus (Wood \& Hammond, 1977) requires active chitin synthase. We have shown, by autoradiography, that new chitin is incorporated into the cell walls during elongation of the stipe, and that incorporation occurs all over the surface of the elongating cells. This nonpolar addition of new wall materials is very different to the mechanism of wall growth observed in vegetative hyphae (Gooday, 1971). Labelled $N$-acetylglucosamine is often incorporated into the septa of stipe hyphae, clearly indicating that new septa are being formed.

\section{Model for cell growth in the elongating stipe}

For each section of the stipe we calculated an expansion factor, namely, the factor by which the section had increased during its growth from the unexpanded to the expanded stage. If no cell division occurs, one would expect the cells to elongate by the same factor. But we often found that the cell lengths did not appear to have increased as much as expected. Our results can be explained if we predict that new septa are laid down and that cell division occurs during expansion. The model we propose assumes that there is a Unit Cell Length, which may vary depending upon the length of the stipe. We propose that an individual cell lengthens by non-polar addition of new wall material, and when the cell attains a length equal to twice the Unit Cell Length, a septum is formed at the middle of the cell. The two new cells continue to elongate until they attain individual lengths equal to twice the Unit Cell Length, when again new septa are formed. The process of individual cell expansion continues as shown in Fig. 6. On this basis, cells occurring in a stipe section which expands fivefold should be smaller than cells in a region which only expands threefold.

Table 5 shows an example of the application of the model, to section I I (top section) of the stipe of fruit body A. This section expanded from 2.5 to $14 \mathrm{~mm}$ so the expansion factor was $5 \cdot 6$. The frequency distribution of the lengths of 100 cells from the unexpanded section I I are listed. In this example there was little variation in cell lengths.

Firstly, the cell lengths were multiplied by the expansion factor (column 3, Table 5). We then determined the Unit Cell Length which, when applied to these figures, gave a predicted mean cell length after expansion as near as possible to the experimentally determined mean cell length: this Unit Cell Length was approximately $56 \mu \mathrm{m}$. Thus to apply the model, every cell length in column 3 (Table 5 ) between 0 and $112 \mu \mathrm{m}$ was left as one cell, lengths between I I 2 and $224 \mu \mathrm{m}$ were divided by 2 to form two new cells, and lengths between 224 and $448 \mu \mathrm{m}$ were divided by 4 to form four new cells. This gave a list of cell lengths (column 4, Table 5), none of which were greater than twice the Unit Cell Length. Since new cells were formed we calculated the new frequency of cells in each case (column 5, Table 5) by multiplying the original frequency by the number of divisions (in this example, either two or four divisions occurred). The new cell lengths were multiplied by the appropriate frequency, totalled and the mean was calculated. The mean cell length predicted for section I I was $77.4 \mu \mathrm{m}$, which is comparable with the experimental value of $85.8 \mu \mathrm{m}$. When this Unit 


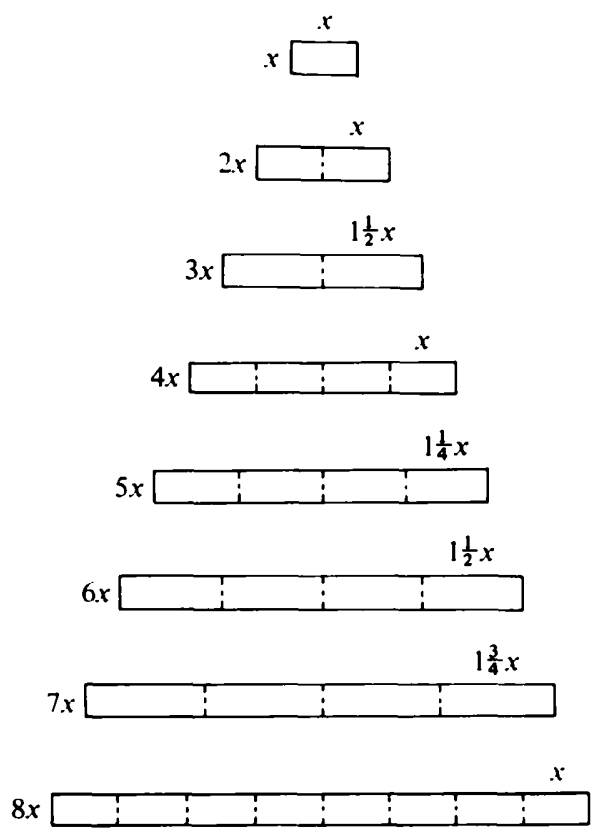

Fig. 6. Model for cell growth in the elongating stipe of Agaricus bisporus.

Table 5. Application of the model to section I I (top section) of the stipe of fruit body $A$ to predict the mean cell length after expansion

For details of the application, see Discussion. The expansion factor was taken as 5.6 and the Unit Cell Length as $56 \mu \mathrm{m}$.

\begin{tabular}{|c|c|c|c|c|c|}
\hline Frequency & $\begin{array}{l}\text { Cell length } \\
(\mu \mathrm{m})\end{array}$ & $\begin{array}{l}\text { Cell length } x \\
\text { expansion factor } \\
(\mu \mathrm{m})\end{array}$ & $\begin{array}{l}\text { Apply model, i.e. } \\
\text { Unit Cell Length } \\
(\mu \mathrm{m})\end{array}$ & $\begin{array}{c}\text { New } \\
\text { frequency }\end{array}$ & $\begin{array}{l}\text { New cell length } \\
\text { new frequency } \\
(\mu \mathrm{m})\end{array}$ \\
\hline 2 & $49 \cdot 5$ & $277 \cdot 2$ & $69 \cdot 3$ & 8 & 554.4 \\
\hline 16 & $31 \cdot 5$ & $176 \cdot 4$ & $88 \cdot 2$ & 32 & $2822 \cdot 4$ \\
\hline 20 & 27.0 & $15 I^{\prime} \cdot 2$ & 75.6 & 40 & $3024 \cdot 0$ \\
\hline 4 & $22 \cdot 5$ & $126 \cdot 0$ & $63 \cdot 0$ & 8 & 504.0 \\
\hline 26 & 36.0 & $201 \cdot 6$ & $100 \cdot 8$ & 52 & $5241 \cdot 6$ \\
\hline 2 & 54.0 & $302 \cdot 4$ & $75 \cdot 6$ & 8 & $604 \cdot 8$ \\
\hline 8 & 45.0 & 252.0 & 63.0 & 32 & 2016.0 \\
\hline 2 & $58 \cdot 5$ & 327.6 & $8 \mathrm{I} \cdot 9$ & 8 & $655 \cdot 2$ \\
\hline 2 & 18.0 & $100 \cdot 8$ & $100 \cdot 8$ & 2 & $201 \cdot 6$ \\
\hline 12 & 40.5 & 226.8 & $56 \cdot 7$ & 48 & $2721 \cdot 6$ \\
\hline \multirow[t]{3}{*}{4} & 13.5 & $75 \cdot 6$ & $75 \cdot 6$ & 4 & $302 \cdot 4$ \\
\hline & 63.0 & $352 \cdot 8$ & $88 \cdot 2$ & 8 & $705 \cdot 6$ \\
\hline & & & Total & 250 & 19353.6 \\
\hline
\end{tabular}

Cell Length $(56 \mu \mathrm{m})$ was used in similar calculations for the other sections of the stipe of fruit body A, the experimental and predicted mean cell lengths were comparable (Table 6).

The model was applied similarly to fruit bodies B, C and D, and again there was good agreement between predicted and experimental values of expanded cell lengths. The best fit Unit Cell Lengths used were approximately $70 \mu \mathrm{m}$ for fruit bodies B and C and $60 \mu \mathrm{m}$ for fruit body D. A plot of Unit Cell Length against the total stipe length after expansion for the four fruit bodies (Fig. 7) shows that the Unit Cell Length increases with stipe length. With the present data it is difficult to assess the significance of this relationship, although it 
Table 6. Experimental and predicted values of mean cell length after expansion in the sections of the stipe of fruit body $A$

\begin{tabular}{|c|c|c|}
\hline \multirow[b]{2}{*}{ Stipe section } & \multicolumn{2}{|c|}{ Mean cell length $(\mu \mathrm{m})$ after expansion } \\
\hline & Experimental & Predicted \\
\hline I (base) & $74 \cdot 8$ & $68 \cdot I^{*}$ \\
\hline 2 & 84.5 & $68 \cdot 8^{*}$ \\
\hline 3 & $77 \cdot 0$ & $67 \cdot 2^{*}$ \\
\hline 4 & $67 \cdot 5$ & $60 \cdot 8^{*}$ \\
\hline 5 & 68.6 & $62 \cdot I^{*}$ \\
\hline 6 & $80 \cdot 1$ & $62 \cdot 4$ \\
\hline 7 & $73 \cdot 8$ & $75 \cdot 6$ \\
\hline 8 & $70 \cdot 7$ & $70 \cdot 7$ \\
\hline 9 & $80 \cdot 5$ & $75 \cdot I$ \\
\hline IO & 73.9 & $83 \cdot 2$ \\
\hline I I (top) & $85 \cdot 8$ & $77 \cdot 4$ \\
\hline
\end{tabular}

* These values are simply the unexpanded mean cell length values. There is no noticeable expansion in the length of these sections, so we would expect the mean cell length after expansion to be approximately the same as the mean cell length before expansion. However, most of these predicted values are lower than the experimental values, probably due to a slight expansion of the section which cannot be measured accurately.

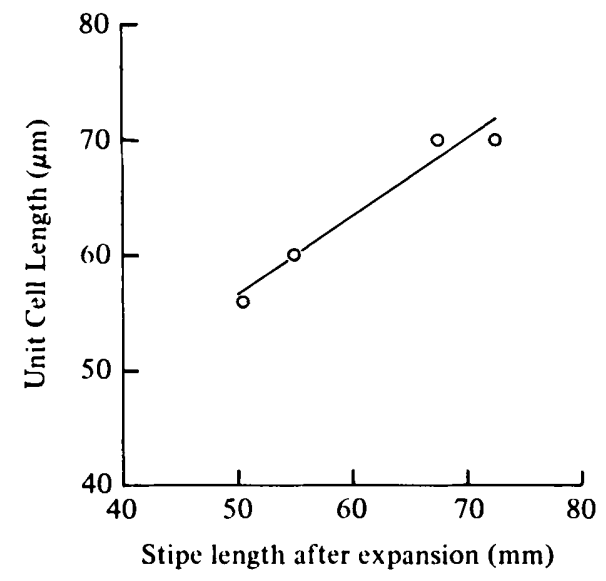

Fig. 7. Variation of Unit Cell_Length with expanded stipe length in fruit bodies A, B, C and D.

is important to note that the average cell length in the whole stipe also increases with stipe length, i.e. the stage of development.

The mechanism of stipe elongation in basidiomycetes is undoubtedly a complex process. Our simple model of cell growth in the stipe of $A$. bisporus does, however, explain the experimental results we have obtained. It indicates that individual cells will elongate by addition of new wall material over their whole surface. The model explains why in stipe regions which expand by large amounts, the cells are not much longer than those found in regions which do not expand much. Our experiments show that cells grow by non-polar addition of new wall materials and that new septa are formed during stipe expansion. Other studies have also shown that septa are usually located at the middle of growing hyphae (Niederpruem \& Jersild, 1972; Fiddy \& Trinci, 1976), as we suggest.

In conclusion, we believe that elongation of much of the lower portion of the $A$. bisporus stipe can be accounted for by cell elongation, but that the expansion of the upper regions is the result of cell elongation and cell division. We are now investigating the mechanisms which control the rate of cell elongation within the stipe. 
We thank Mr R. J. Newsam for his excellent technical assistance and Mr D. C. Millar for providing the samples of compost. G. D. Craig thanks the Science Research Council for a CASE research studentship.

\section{REFERENCES}

BONNER, J. T., KANE, K. K. \& LeVey, R. H. (1956), Studies on the mechanics of growth in the common mushroom, Agaricus campestris. Mycologia 48, I3-19.

Corbett, J. R. (1974). The Biochemical Mode of Action of Pesticides. London and New York: Academic Press.

Cox, R. J. \& Niederpruem, D. J. (1975). Differentiation in Coprinus lagopus. III. Expansion of excised fruit bodies. Archives of Microbiology r05, 257-260.

EILERS, F. I. (1974). Growth regulation in Coprinus radiatus. Archives of Microbiology 96, 353-364.

FIDDY, C. \& Trinci, A. P. J. (1976). Mitosis, septation, branching and the duplication cycle in Aspergillus nidulans. Journal of General Microbiology 97, 169-184.

GoODAY, G. W. (1971). An autoradiographic study of hyphal growth of some fungi. Journal of General Microbiology 67, 125-133.

GoODAY, G. W. (1972). The role of chitin synthetase in the elongation of fruit bodies of Coprinus cinereus. Journal of General Microbiology 73, xxi.

GoODAY, G. W. (1973). Activity of chitin synthetase during the development of fruit bodies of the toadstool Coprinus cinereus. Biochemical Society Transactions 1, 1105-1 107.
Gooday, G. W., de Rousset-Hall, A. \& Hunsley, D. (1976). Effect of polyoxin D on chitin synthesis in Coprinus cinereus. Transactions of the British Mycological Society 67, 193-200.

HaGimoto, H. (I964). The growth of the fruit body of Agaricus bisporus (Lange) Sing. Transactions of the British Mycological Society 4, $158-164$.

Hagimoto, H. \& Konishi, M. (1959). Studies on the growth of the fruit body of fungi. I. Existence of a hormone active to the growth of the fruit body in Agaricus bisporus (Lange) Sing. Botanical Magazine, Tokyo 72, 359-366.

Hagimoto, H. \& Konishi, M. (1960). Studies on the growth of the fruit body of fungi. II. Activity and stability of the growth hormone in the fruit body of Agaricus bisporus (Lange) Sing. Botanical Magazine, Tokyo 73, 283-287.

Niederpruem, D. J. \& Jersild, R. A. (1972). Cellular aspects of morphogenesis in the mushroom Schizophyllum commune. CRC Critical Reviews in Microbiology 1, 545-576.

Wood, D. A. \& HAMMOND, J. B. W. (1977). Inhibition of growth and development of Agaricus bisporus by polyoxin D. Journal of General Microbiology 98, 625-628. 